\title{
Determinants of Dividend Policy for Companies Listed at Dar Es Salaam Security Exchange (DSE), a Case of Selected Listed Companies
}

\author{
Magambo Evelyne F. \\ Accountancy Department, College of Business Education, Mwanza, Tanzania \\ Email address: \\ e.magambo@cbe.ac.tz
}

\section{To cite this article:}

Magambo Evelyne F. Determinants of Dividend Policy for Companies Listed at Dar Es Salaam Security Exchange (DSE), a Case of Selected Listed Companies. Journal of Finance and Accounting. Vol. 4, No. 4, 2016, pp. 202-211. doi: 10.11648/j.jfa.20160404.16

Received: May 10, 2016; Accepted: June 23, 2016; Published: July 6, 2016

\begin{abstract}
The main objective of the study was to establish the determinants of dividend policies of companies listed at DSE. Specifically, the study aimed to identify factors that influence dividend policy among listed companies and explore the statistical relationship between determinants of dividend policy. Correlation and regression analysis were used to establish the relationship between the dependent and independent variables. The study concludes that the dividend policies of companies listed at the DSE is determined by the amount of profit after tax, liquidity and shareholders' fund. Among these four determinants, Profitability is the most significant determinant of dividend policy. The study recommends that listed company should adopt dividend policy based on their current financial circumstances, especially, based on their current Profitability position. Also DSE should conduct frequent training to shareholders of various companies listed at DSE so as to help them make sound financial decisions with regard to which companies to buy shares from.
\end{abstract}

Keywords: Dividend Policy, Listed Companies, Dares Salaam Stock Exchange, Tanzania

\section{Introduction}

A stock exchange is a market that deals with the exchange of securities issued by listed companies. Capital markets facilitate the trading of instruments with maturity period of more than one year such as bonds, debentures, stocks and collaterals. Taking the example of developed economies, capital markets are the principal means through which companies raise capital to expand their operations. To be able to trade a security on a certain stock exchange, a company has to be listed.

Dar es Salaam Security Exchange (DSE)

Dar es Salaam Security Exchange (DSE) was incorporated in September 1996 as a company limited by guarantee without a share capital. The formation of the DSE followed the establishment of the Capital Markets and Securities Authority (CMSA) by the Capital Markets and Securities Act, 1994. DSE initially began its operations as an Over-TheCounter (OTC) stock market (DSE, Blueprint 2011).

DSE is made up of players such as agents, dealers, stockbrokers and listed companies. Until December, 2012, the number of companies listed at DSE was 11. Some of the companies listed with DSE included SWISSPORT, Tanzania Breweries Limited (TBL), Tanzania Cigarette Company (TCC), Simba Cement and Tanzania Tea Packers (TATEPA), (www.dse.co.tz/sites/default/files/dsefiles/DOMESTIC\%20L ISTED\%20COMPANIES).

\section{Dividend Policy}

Dividends are payments made by a corporation to its shareholders from its corporate profits. When a corporation earns a profit or surplus, that money can be put to two uses: it can either be re-invested in the business, or it can be distributed to shareholders.

The dividend policy of a company relates to the decisions regarding the distribution of profits in the form of dividends and retention of profits for further use in the business (Modigliani and Miller, 1961).

The dividend policy outlines the framework within which dividends are to be managed covering details of whether to pay or not, what frequency, the modes and types or combinations and indeed the scheduling of events (Pandey, 2001). 
There is considerable debate on how dividend policy affects firm value. Some researchers believe that dividends increase shareholder wealth (Gordon, 1959), others believe that dividends are irrelevant (Miller and Scholes, 1978), and still others believe that dividends decrease shareholder wealth (Litzenberger and Ramaswamy, 1979). Therefore dividend policy of a firm is a significant aspect of corporate management.

Dividend policy of a company has potential implications for share prices, the financing of internal growth (through retentions), the size of the equity base within the firm (through retentions) and hence the gearing (Leverage) ratio (Gordon, 1959). La Porta, et al., (2000), suggested that dividend policy variations across countries are explained by differences in their legal systems. They found that firms in countries with better shareholder protections (Common Law) made higher dividends payout than those in civil law countries. In mature markets such as the UK, dividends have a stronger impact on share values than retained earnings.

The dividend policy of firms is one of the most important research topics in the finance literature for most of the last four decades since the publication of the seminal paper on the irrelevance of dividend policy by Modigliani and Miller (1961). The dividend policy of a company relates to the decisions regarding the distribution of profits in the form of dividends and retention of profits for further use in the business.

The two objectives of dividend policy, distribution of dividends and retention of earnings for growth are in conflict. Black, (1976), in his study described issues on dividends as a puzzle "The harder we look at the dividend picture, the more it seems like a puzzle, with the pieces that just don't fit together. What should the corporation do about dividend policy? We don't know".

According to Baker et al. (2002), dividend policy remains one of the more puzzling issues in corporate Finance.

\subsection{Statement of the Problem}

There are conflicting theories on determinants of dividend policy among companies listed in stock markets. It is not yet clear what determines the dividend policy. The earliest major attempt to explain dividend behavior of companies has been credited to John Lintner (1956) who conducted his study on American Companies in the middle of 1950s. Since then there has been an ongoing debate on dividend policy in the developed markets resulting in mixed, controversial and inconclusive results.

While Baker et al., (2002) and other researchers argue that dividend policy is significantly affected by investment opportunities available Naila (2007) and others argue that the most significant determinant of dividend policy is company's profitability.

In Tanzania, issues of dividend policy are discussed by listed companies during their Annual General Meetings (AGMs). The decision to declare dividends lies with the Directors but approval is sanctioned at the AGM or at an extraordinary general meeting. However, it is not clear as to what factors determine the decisions made on dividend policy. Hence there is a knowledge gap on the subject matter.

Moreover, while many studies have been conducted on companies listed in at the Dar es Salam Stock Exchange, most of the studies have focused on challenges facing DSE, effectiveness of DSE, impact of listing a company at DSE, requirements of listing a company with DSE, etc. No studies have been conducted on determinants of dividend policy for companies listed with DSE. Hence, there is a knowledge gap.

\subsection{Objectives of the Study}

The main objective of the study is to examine determinants of dividend policy among companies listed at the Dar es Salaam Stock Exchange (DSE).

The specific objectives are to identify factors that influence dividend policy among listed companies and to explore the statistical relationship between determinants of dividend policy.

\subsection{Research Hypotheses}

Hence this study was guided by the following research hypothesis;

H1: Dividend policy of listed companies is determined by profit after tax

H2: Dividend policy of listed companies is determined by shareholder fund

H3: Dividend policy of listed companies is determined by Liquidity position

H4: Dividend policy of listed companies is determined by financial Leverage

\subsection{Significance of the Study}

This study will be of importance to various stakeholder groupings and to business scholarship. First, it will help managers to identify the dividend policy their company uses and how their decisions affect such policies. Shareholders too stand to gain from the study. It is important for them to know how their company determines its dividend policy and how the policies affect their wealth.

Investors will be enlightened on the possibility of being misled by information presented by managers to seduce them to invest their funds in various companies. Lastly, this study will make an important input to theory. Its results will add to the Dividend Policy Theory.

\section{Literature Review}

\subsection{Theoretical Literature Review}

\section{Dividend Irrelevance Theory}

This theory purports that a firm's dividend policy has no effect on either its value or its cost of capital. Investors are indifferent to dividends and capital gains. MM, (1961), demonstrates under the assumptions of a rational investor and a perfect capital market, the market value of the firm is independent of its dividend policy. Dividend is indeed 
irrelevant.

Under their assumptions, the value of the firm is determined solely by its earnings power and investment decisions. Investment decisions are independent of financing decisions such as debt or dividends because in perfect capital markets, the value of a firm is affected only by its investment decision. In addition, both the financing decision and dividend policy are irrelevant in the process of determining the firm's value.

Empirical support for the dividend irrelevance theory is limited as the real world is full of irrationality and the markets are neither perfect nor efficient (Shiller, 2003).

Bird-in-the-hand theory

This is one of the major theories about dividend policy in an enterprise. The theory was developed by Gordon (1963) and Lintner (1962) as a response to Modigliani and Miller's dividend irrelevance theory. The theory asserts that in a world of uncertainty and information asymmetry dividends are valued differently to retained earnings (capital gains). Because of uncertainty of future cash flow, investors often tend to prefer dividends to retained earnings. Higher payout ratio reduce the required rate of return (cost of capital), and hence increase the value of the firm.

Models for the "bird-in-the-hand" work on the implicit assumption that there are two opportunity rates (marginal rates of investment): one for the firm and another one for the investors. If the firm's opportunity rate is higher than that of the investors', then the firm should retain $100 \%$ of its earning. If the investors' opportunity rate is higher than the firm's is, $100 \%$ of the earning should be paid out as dividends.

MM, (1961) however dismisses the theory as a fallacy and so does Bhattacharya, (1979) by arguing that the riskiness of a firm is determined by its cash flow and not by consistency of dividend payout. The Enron scandal and other corporate abuses shook investor confidence- Julio, et al., (2004). Promoters of the signaling theory would argue the change in dividend policy is a signal to increased dividend payouts in the future.

Some authors argue that the payment of dividends is lack of nothing better to do with its funds. Forbes, et al., (1998), examining the connection between share price and dividend amount on the New York Stock Exchange (NYSE) finds that although predominantly low priced shares do not pay dividends during the 1970s and 1980s, the pattern changes, with more firms beginning to pay dividends by end of 1993 .

Agency Theory

The theory is premised on the separation of ownership and control. Managers may conduct business in accordance to their own self-interest that may not necessarily be beneficial to the shareholders. For example, managers may spend lavishly on perquisites or over-invest to enlarge the size of their firms beyond the optimal size (Miller and Modigliani, 1961).

The agency costs thesis, posits that the excess cash flow under management control can be reduced through dividend payments hence forcing the management into capital markets thus putting them under scrutiny of the capital suppliers.
Lenders prefer firms accumulate cash than pay dividends. Indeed, Leverage has special clauses to sanction retention or payments beyond a certain thresholds (Miller and Modigliani, 1961).

The Free Cash Flow Hypothesis

This is just a minor variant of the agency argument. All else being equal, firms pay dividends from cash flows that cannot be reinvested in positive net present value projects (free cash flows). Prudent corporate managers working in their shareholders' best interest should invest in all profitable opportunities. However, management and owner separation affords managers the temptations to consume surplus funds (Jensen, 1986).

Jensen coins the free cash flow hypothesis by combining the agency theory with the market information asymmetries. The funds remaining after financing all positive net present value projects cause conflicts of interest between managers and shareholders.

Dividends and debt interest payments decrease the free cash flow that managers otherwise use to investment in marginal net present value projects and perquisite consumptions. Barber, et al., (1992) opines that the free cash flow hypothesis and the signaling are complementary rather than competing. Neither the information content hypothesis, nor the agency cost theory sufficiently explains dividend policy.

\section{Pecking Order Theory}

The theory as developed by Myers, et al., (1984); states that companies prioritize their sources of financing (from internal financing to external equity) according to the law of least effort, or of least resistance, preferring to raise equity as a financing means of last resort. Hence, internal funds are used first, and when that is depleted, debt is issued, and when it is not sensible to issue more debt, equity is issued (Myers, 1984).

The theory maintains that firms adhere to a hierarchy of financing sources and prefer to issue debt than equity, if internal finance is insufficient. The theory lays out the linkages between the firm's capital structure, dividend and investment policies. The theory suggests that firms prefer to use internal equity to pay dividends and finance new investments. It ranks internal equity at the top of the pecking order (Myers, 1984).

Donaldson (1961) suggests that internal equity is preferred because firms want to avoid flotation costs which usually accompany external finance. Raising debt is also cheaper than external equity funding. Myers (1984) disagrees with the notion of floatation costs and argues that the net benefits of debt financing in terms of tax shield and risk of financial distress are likely to outweigh floatation costs.

The sale of new shares is not in the interest of existing shareholders because it usually leads to decrease in the market price, dilution of control and decrease in earnings per share of the existing shares, as evidenced by Masulis, et al., (1986).
Types of Dividend Policy
Constant or fixed policy 
The Company pays out a fixed amount of its profit after tax as dividend. Thus, the company maintains a fixed payout ratio of dividend. A company may as a matter of policy, decide to constantly payout sixty percent of its after tax profit as dividend to its shareholders and retaining the remaining fraction. This type of policy allows the shareholders the opportunity to clearly know the amount of dividend to expect (Watson and Head, 2004).

However as noted by Watson and Head (2004), the policy could be traumatic to companies experiencing a volatile or fluctuating profit earning. This is because of the uncertainty of its profit. Progressive policy: Payments of dividend is on a steady increase usually in line with inflation. This could result in increasing dividend in money terms.

\section{Residual policy}

Dividends are just what is left after the company determines the retained profits required for the future investment. This policy gives preference to its positive NPV (Net Present Value) projects and paying out dividends if there are still left over funds available. Dividend becomes a circumstantial payment only paid when the investment policy is satisfied (Kolb and Rodriguez, 1996).

With residual dividend policy, there is a tendency therefore that this type of policy could give rise to a zero dividend structure. Firms which use residual dividend policy may need to modify this policy to ensure that investors of the different clienteles are not chased out by a strict application of the policy (Kolb and Rodriguez, 1996).

Zero dividend policy

This policy is common in newly formed companies that rather require capital to execute its projects. All the profit is thus retained for expansion of the business. Investors who prefer capital gains to dividends because of taxation will naturally be lured by this kind of policy. This type of policy is easy to operate and avoids all the costs associated with payment of dividends (Watson and Head, 2004).

\subsection{Empirical Literature Review}

As such, dividends and control concentrations are substitute monitoring mechanisms. Widely dispersed shareholding can give rise to severe agency costs; higher dividend payout can also reduce agency costs, by increasing the likelihood that the firm has to raise outside financing and, in turn, be subject to scrutiny of the capital markets for new funds thus reducing the risk of suboptimal investment. Following Rozeff (1982) and Easterbrook, (1984), concentrated holdings can mitigate the need for costly dividends to reduce agency costs. Rozeff (1982) finds support for the role of dividends in resolving agency costs in minority-manager-controlled firms. His analysis shows a negative relationship between dividends payout and the percentage of insiders.

A number of studies have looked at the determinants of dividend payout and the relationship that exist among them. Saidi (2006) in his study about the factors affecting dividend payout concluded that firm's dividend decision is significantly affected by the investment opportunities available. When a firm has many investment opportunities it will use its profits to take advantage of the viable projects. Therefore for this case the firm will not prefer to pay dividends.

Naila (2007) found that the most important factor in determining dividend policy issues is the company's current and future profitability and firm's Liquidity. Same findings were obtained by Njuguna (2006). They concluded that, current and future profitability and liquidity are key determinants of a firm's dividend policy. Researchers have found conflicting results on whether variables profits and cash flows affected dividends or not.

According to Baker, Veit, and Powell (2001), firms with higher Levels of debt also need higher Levels of Liquidity to allow for payoffs on potential implicit claims. These firms are more conservatively financed, use more equity, and maintain a higher Level of liquidity to avoid the costs of financial distress. To increase Liquidity, firms might lower dividend payouts. Lower payouts mean firms will need less outside financing, since they are retaining cash internally to strengthen Liquidity. Thus, we expect a negative relationship between Liquidity and dividend payout since the more cash paid out to investors in the form of dividends would reduce the cash on hand to the firm.

Firms with larger profits are more likely to pay a dividend (Banerjee, Gatchev \& Spindt, 2002). Departures from this level are made reluctantly, following a change in the level of profits, which is deemed to be more or less permanent. Companies that are facing uncertainty about future profits would adopt a lower payout ratio as a means of hedging the risk of having to cut their dividend in the future (Friend \& Puckett, 1964).

Several theories have failed to address the dividend behaviour for two reasons: Financial economists have been developing a universal or "one-fits all" explanation despite the fact that dividend policy is sensitive to such factors as firm characteristics, corporate governance, and legal environments. The proposed explanations rely heavily on economic, modeling approaches.

A study to establish what explains and determines the dividend policy as subscribed by the main stream dividend theories and to what extent are the significant determinants statistically correlated will help customize the dividend puzzle to our local environment as far as the management and shareholders are concerned and as it applies to the Tanzanian companies listed on the DSE as at end of 2012.

\section{Research Design}

The research design was both qualitative and quantitative in its approach. The qualitative approach adopts descriptive and inductive forms of research. Statistical models are used in analyzing data obtained in the study. The method of analysis was correlation as it employs statistical tools in analyzing data obtained for the study. Data was obtained from the financial statements of selected companies listed on DSE. 
In considering a descriptive research, well-detailed information on the nature of the problem was carried out. In this case, dividend payout, profit after tax, shareholders fund, Liquidity, risk and financial Leverage were analysed. The analysis involved application of econometrics models involving various variables such as; dividend, profit after tax, shareholders fund, Liquidity and Leverage.

Correlation was used to measure the strength of association between dependent and independent variables. Correlation was also used to show the strength of association between dependent variable and independent variables.

The data obtained was fitted to the equation by ordinary least-square (OLS with random effect) regression method which is expected to produce the best estimate. The linear relationship between the dependent and the independent variables were determined. Multiple regressions were used for the regression analysis and inferences were drawn based on the analysis.

\subsection{Data Collection}

The main source of data for the study was audited financial statement of the sampled companies from 2005 to 2012. The data was collected from annual reports of the companies as well as proceedings from Annual General Meetings (AGMs) of the companies.

The population of study comprised of all companies listed within DSE by 2012. Currently, DSE has 23 companies that are listed. From among the population, the researcher selected a sample of four companies that have been listed between 2005 throughout to 2012. Purposive sampling technique was used to select listed companies based in the following criteria; Companies with regular annual report, positive earnings, dividend payout history, more than ten years of incorporation and eight years or more of listing at DSE.

The reason behind using the above mentioned criteria is that it provided the researcher with the variables to be regressed to ascertain the significance of the determinants of dividend policy. The criteria also provided the researcher with reliability and validity of the data used for the regression analysis.

Therefore four companies were selected namely; SWISSPORT, Tanzania Breweries Limited (TBL), Tanzania Cigarette Company (TCC) and Simba Cement.

\subsection{Research Variables}

The variables used in this study are based on previous researches done on the subject.

Dividend Payout $\left(\mathrm{DPO}_{\mathrm{t}}\right)$ servesas the dependent variable while Profit After Tax $\left(\mathrm{PAT}_{\mathrm{t}}\right)$, Shareholders Fund $\left(\mathrm{SHF}_{\mathrm{t}}\right)$, LIQuidity $\left(\mathrm{LIQ}_{\mathrm{t}}\right)$ and Financial LEVerage $\left(\mathrm{LEV}_{\mathrm{t}}\right)$ are independent variables. Multiple regressions were used to determine the variability of the variables. A positive correlation implies that as one variable increases in value, the other variable also increases. A negative correlation indicates that when one variable increases the other variable decreases. Also, the closer the correlation value is to 1 , the stronger the relationship between the variables.

\subsection{Model Specification}

The following relationships between variables were analysed;

$$
\begin{aligned}
& D P O_{t}=f\left(P A T_{t}\right) \\
& D P O_{t}=f\left(S H F_{t}\right) \\
& D P O_{t}=f\left(L I Q_{t}\right) \\
& D P O_{t}=f\left(L E V_{t}\right)
\end{aligned}
$$

While the above equations served as the main models the following linear equations were used;

$$
\begin{aligned}
& D P O_{t}=\alpha_{o}+\alpha_{1} P A T_{t}+\varepsilon_{t} \\
& D P O_{t}=\beta_{o}+\beta_{1} S H F_{t}+\varepsilon_{t} \\
& D P O_{t}=\delta_{o}+\delta_{1} L I Q_{t}+\varepsilon_{t} \\
& D P O_{t}=\psi_{o}+\psi_{1} L E V_{t}+\varepsilon_{t}
\end{aligned}
$$

Here $\varepsilon_{t}$ is the error term.

\section{Findings and Discussion}

\section{Dependent and independent variables}

Table 1 presents the mean data of the sampled companies used for the regression analysis. In the model used, profit after tax (PAT), shareholders fund (SHF), Liquidity (LIQ), and financial Leverage (LEV) are independent variables while dividend payout (DPO) is the dependent variable for the five regression equations.

Where:

$\mathrm{DPO}_{\mathrm{t}}=$ Dividend payout represented by the amount paid out as dividen during the year.

$\mathrm{PAT}_{\mathrm{t}}=$ Profit After Tax

\begin{tabular}{|c|c|c|c|c|c|c|c|c|}
\hline Variable & & Mean & Std. Dev. & Min & Max & Observations & & \\
\hline \multirow[t]{3}{*}{$\mathrm{DPO}$} & Overall & $2.23 \mathrm{E}+07$ & $2.24 \mathrm{E}+07$ & 0 & $6.64 \mathrm{E}+07$ & $\mathrm{~N}=32$ & Variance & $5.02 \mathrm{E}+14$ \\
\hline & Between & & $2.08 \mathrm{E}+07$ & 3344375 & $4.96 \mathrm{E}+07$ & $\mathrm{n}=4$ & Skewness & 0.822096 \\
\hline & Within & & $1.30 \mathrm{E}+07$ & $-2.17 \mathrm{E}+07$ & $5.56 \mathrm{E}+07$ & $\mathrm{~T}=8$ & Kurtosis & 2.041531 \\
\hline PAT & Between & & $3.57 \mathrm{E}+07$ & 4467125 & $8.82 \mathrm{E}+07$ & $\mathrm{n}=4$ & Skewness & 1.380541 \\
\hline
\end{tabular}

$\mathrm{SHF}_{\mathrm{t}}=$ Shareholders Fund represented by the difference between Total assets and Total liabilities

$\mathrm{LIQ}_{\mathrm{t}}=$ Liquidity represented by the amount of cash and cash equivalents

$\mathrm{LEV}_{\mathrm{t}}=$ Financial Leverage represented by long term borrowing

Table 1. Descriptive Statistics. 


\begin{tabular}{|c|c|c|c|c|c|c|c|c|}
\hline Variable & & Mean & Std. Dev. & Min & Max & Observations & & \\
\hline \multirow{4}{*}{ SHF } & Within & & $2.28 \mathrm{E}+07$ & -153761 & $1.19 \mathrm{E}+08$ & $\mathrm{~T}=8$ & Kurtosis & 4.81692 \\
\hline & Overall & $9.19 \mathrm{E}+07$ & $8.92 \mathrm{E}+07$ & 5559000 & $3.99 \mathrm{E}+08$ & $\mathrm{~N}=32$ & Variance & $7.96 \mathrm{E}+15$ \\
\hline & Between & & $7.38 \mathrm{E}+07$ & 8035875 & $1.87 \mathrm{E}+08$ & $\mathrm{n}=4$ & Skewness & 1.680417 \\
\hline & Within & & $6.12 \mathrm{E}+07$ & 5920934 & $3.03 \mathrm{E}+08$ & $\mathrm{~T}=8$ & Kurtosis & 6.246531 \\
\hline \multirow[t]{3}{*}{ LIQ } & Overall & $1.50 \mathrm{E}+07$ & $2.00 \mathrm{E}+07$ & 497000 & $1.01 \mathrm{E}+08$ & $\mathrm{~N}=32$ & Variance & $4.01 \mathrm{E}+14$ \\
\hline & Between & & $1.04 \mathrm{E}+07$ & 2725000 & $2.76 \mathrm{E}+07$ & $\mathrm{n}=4$ & Skewness & 2.802034 \\
\hline & Within & & $1.78 \mathrm{E}+07$ & -4576147 & $8.79 \mathrm{E}+07$ & $\mathrm{~T}=8$ & Kurtosis & 11.71776 \\
\hline \multirow[t]{3}{*}{ LEV } & Overall & $1.42 \mathrm{E}+07$ & $2.39 \mathrm{E}+07$ & 636000 & $9.22 \mathrm{E}+07$ & $\mathrm{~N}=32$ & Variance & $5.73 E+14$ \\
\hline & Between & & $1.53 \mathrm{E}+07$ & 1804500 & $3.65 \mathrm{E}+07$ & $\mathrm{n}=4$ & Skewness & 2.597377 \\
\hline & Within & & $1.98 \mathrm{E}+07$ & $-1.84 \mathrm{E}+07$ & $6.99 \mathrm{E}+07$ & $\mathrm{~T}=8$ & Kurtosis & 8.396852 \\
\hline
\end{tabular}

Source: Author's estimation using STATA 12

Table 1 above shows that the dataset is a balanced panel data with a total of 32 observations which were taken from 4 companies and each company was observed for a period of 8 years. However it shows that the mean DPO for all the companies is $2.23 \mathrm{E}+7$, mean PAT is 4.04E+7, mean SHF 9.19E+07.

Moreover all the variables have skewness close to zero and kurtosis close to 3 which imply that their normally distributed and there are no outliers. In order to verify if the variables are normally distributed this study conducted normality test based on skweness and kurtosis test and was verified by Shapiro and Wilk test; the findings are shown in the table $2 \mathrm{a}$ and $2 \mathrm{~b}$ below:

Table 2a. Normality test based on Skewness and kurtosis.

\begin{tabular}{llllll}
\hline Variable & Observations & Pr (Skewness) & Pr (Kurtosis) & Adj chi2 (2) & Prob>chi2 \\
\hline DPO & 32 & 0.0412 & 0.1314 & 6 & 0.0498 \\
PAT & 32 & 0.0019 & 0.0329 & 11.32 & 0.0035 \\
SHF & 32 & 0.0004 & 0.0048 & 15.6 & 0.0004 \\
LIQ & 32 & 0 & 0 & 28.51 & 0 \\
LEV & 32 & 0 & 0.0005 & 24.23 & 0 \\
\hline
\end{tabular}

Source: Author's estimation using STATA 12

Table 2a shows that the joint probabilities of all variables in the analysis are less than 0.05 which imply that the p-value is significant at 5 percent Level of significance, thus we can reject the null hypothesis that the variables are not normally distributed. Therefore the variables are normally distributed.

Table 2b. Normality test based on Shapiro-Wilk W Test for normal data.

\begin{tabular}{llllll}
\hline Variable & Obs & W & V & Z & Prob $>\mathbf{z}$ \\
\hline DPO & 32 & 0.80481 & 6.511 & 3.889 & 0.00005 \\
PAT & 32 & 0.85474 & 4.846 & 3.276 & 0.00053 \\
SHF & 32 & 0.82833 & 5.726 & 3.623 & 0.00015 \\
LIQ & 32 & 0.65443 & 11.527 & 5.075 & 0 \\
LEV & 32 & 0.54202 & 15.277 & 5.66 & 0 \\
\hline
\end{tabular}

Source: Author's estimation using STATA 12

Table $2 \mathrm{~b}$ presents the findings from Shapiro-Wilk W test for normal data, the p-values are all very small and less than 0.05 which implies that they are significant at 5 percent Level of significance, thus we can also reject the null hypothesis that the data are not normal.

Table 3. Correlation matrix between the variables.

\begin{tabular}{llllll}
\hline & DPO & PAT & SHF & LIQ & LEV \\
\hline DPO & 1 & & & & \\
PAT & 0.729 & 1 & 1 & 1 & \\
SHF & 0.5896 & 0.9633 & 0.8818 & 1 & 1 \\
LIQ & 0.4194 & 0.8201 & 0.8867 & 0.759 & 1 \\
LEV & 0.3154 & 0.817 & & \\
\hline
\end{tabular}

Source: Author's estimation using STATA 12

Table 3 above shows the correlation between the variables. The results show that all variables are positively correlated to each other; moreover it was found that PAT is highly correlated to all variables.

After checking the properties of the data and verify that the use of Ordinary Least Square (OLS) will produce the best estimates. However, the study used Hausman test to choose the best model between OLS with fixed effect or with random effect the findings are shown in the table 4 below; 
Table 4. Hausman Test.

\begin{tabular}{|c|c|c|c|c|}
\hline & (b) & (B) & $(\mathbf{b}-\mathbf{B})$ & Sqrt (diag (V_b-V_B)) \\
\hline & Fixed & & Difference & S. E. \\
\hline$\overline{\mathrm{DPO}}$ & 0.625637 & 0.035541 & 0.590096 & 0.265664 \\
\hline \multicolumn{5}{|c|}{$\mathrm{b}=$ consistent under Ho and Ha; obtained from xtreg } \\
\hline \multicolumn{5}{|c|}{$\mathrm{B}=$ inconsistent under $\mathrm{Ha}$, efficient under Ho; obtained from xtreg } \\
\hline \multicolumn{5}{|c|}{ Test: Ho: Difference in coefficients is not systematic } \\
\hline \multicolumn{5}{|c|}{$\operatorname{Chi} 2(1)=(b-B)^{\prime}\left[\left(V_{-} b-V_{-} B\right)^{\wedge}(-1)\right](b-B)$} \\
\hline \multicolumn{5}{|l|}{4.93} \\
\hline Prob $>$ chi $2=0.0263$ & & & & \\
\hline
\end{tabular}

Source: Author's estimation using STATA 12

Table 4 shows that the p-value of 0.0263 is less than 0.05 which implies that it is significant at 95 percent Level of significance. Therefore we can reject the null hypothesis that the difference in coefficients is not systematic, thus we use the model with random effect. The findings for regression with random effects are presented below.

Table 5a. Analysis of Variance (ANOVA) between DPO and SHF.

\begin{tabular}{|c|c|c|c|}
\hline Random-effects OLS regression & Number of observation & $=$ & 32 \\
\hline Group variable: id & Number of groups & $=$ & 4 \\
\hline R-sq: within $=0.0038$ & Observation per group: min & $=$ & 8 \\
\hline between $=0.9074$ & Average & $=$ & 8 \\
\hline \multirow[t]{2}{*}{ overall $=0.3476$} & Max & $=$ & 8 \\
\hline & Wald chi2 (1) & $=$ & 5.46 \\
\hline Corr $\left(\mathrm{u} \_\mathrm{i}, \mathrm{X}\right)=0$ (assumed) & Prob $>$ chi 2 & $=$ & 0.0195 \\
\hline
\end{tabular}

Source: Author's estimation using STATA 12

Table 5a shows that the model fitted between DPO and SHF has $\mathrm{R}^{2}$ of 0.35 which implies that SHF explain the overall variation of DPO by 35 percent, also the probability of 0.019 is significant at 95 percent level of significance thus the joint hypothesis that SHF has no influence on DPO can be rejected.

Table 5b. Coefficient Estimate between DPO and SHF.

\begin{tabular}{llllll}
\hline DPO & Coef. & Std. Err. & $\mathbf{z}$ & $\mathbf{z P}>\mathbf{z}$ & [95\% Conf. Interval] \\
\hline SHF & 0.092568 & 0.039625 & 2.34 & 0.019 & 0.014905 \\
cons & $1.38 \mathrm{E}+07$ & 5813917 & 2.37 & 0.018 & 2362158 \\
Sigma_u & 5981008 & & & & $2.52 \mathrm{E}+07$ \\
Sigma_e & 13881513 & & & \\
Rho & 0.156575 & (fraction of variance due tou i) & & \\
\hline
\end{tabular}

Source: Author's estimation using STATA 12

Table 5b shows that the coefficient between SHF and DPO is 0.093 , this implies that there is positive relationship between the two variables which was also observed from the correlation matrix (see table 3 ). However the relationship is in line with the theoretical prediction. Moreover the findings suggest further that the relationship between the two variables is significant at 95 percent as the p-value of 0.019 is less than 0.05 Level of confidence. Thus the coefficient between SHF and DPO is 0.093 which suggests that when SHF increases by 1 unit then DPO will increase by 0.093 unit.

Table 6a. Analysis of Variance (ANOVA) between DPO and LIQ.

\begin{tabular}{|c|c|c|c|}
\hline Random-effects OLS regression & Number of observation & $=$ & 32 \\
\hline Group variable: id & Number of groups & $=$ & 4 \\
\hline R-sq: within $=0.0126$ & Observations per group: min & $=$ & 8 \\
\hline Between $=0.9383$ & Average & $=$ & 8 \\
\hline & Wald chi2 (1) & $=$ & 3.79 \\
\hline Corr $\left(\mathrm{u} \_\mathrm{i}, \mathrm{X}\right)=0$ (assumed) & Prob $>$ chi 2 & $=$ & 0.0516 \\
\hline
\end{tabular}

Source: Author's estimation using STATA 12

Table 6a shows that the model fitted between DPO and LIQ has $\mathrm{R}^{2}$ of 0.18 which implies that LIQ explain the variation of DPO by 18 percent, also the prob of 0.0516 is insignificant at 95 percent Level of significance thus the joint hypothesis that LIQ has no influence of on DPO cannot be rejected. Same finding was obtained by Baker et al (2001). 
Table 6b. Coefficient Estimate between DPO and LIQ.

\begin{tabular}{llllll}
\hline DPO & Coef. & Std. Err. & $\mathbf{Z}$ & zP>Z & [95\% Conf. Interval] \\
\hline LIQ & 0.335404 & 0.17235 & 1.95 & 0.052 & -0.00239 \\
_cons & $1.72 \mathrm{E}+07$ & 4927327 & 3.5 & 0 & 7584024 \\
Sigma_u & 3996774 & & & & $2.69 \mathrm{E}+07$ \\
Sigma_e & 13819991 & & & \\
Rho & 0.077183 & (fraction of variance due to u_i) & & \\
\hline
\end{tabular}

Source: Author's estimation using STATA 12

Table $6 \mathrm{~b}$ shows that the coefficient between DPO and LIQ is 0.33 , this implies that there is positive relationship between the two variables which was also observed from the correlation matrix (see table 3 ). The relationship conforms to the theoretical prediction. Moreover the findings suggest further that the relationship between the two variables is insignificant at 95 percent as the p-value of 0.052 is greater than 0.05 Level of confidence. The coefficient between LIQ and DPO is 0.33 which suggests that when LIQ increase by 1 unit then DPO will increase by 0.33 unit.

Table 7a. Analysis of Variance (ANOVA) between DPO and LEV.

\begin{tabular}{llll}
\hline Random-effects OLS regression & Number of observations & $=$ & 32 \\
Group variable: id & Number of groups & $=$ & 4 \\
R-sq: within $=0.0421$ & Observations per group: min & $=$ & 8 \\
between $=0.8095$ & Average & $=$ & 8 \\
overall $=0.0995$ & max & $=$ & 8 \\
& Wald chi2 (1) & $=$ & 0.04 \\
Corr $(\mathrm{u}$ i, $\mathrm{X})=0$ (assumed) & Prob $>$ chi2 & & 0.8486 \\
\hline
\end{tabular}

Source: Author's estimation using STATA 12

Table 7a shows that the model fitted between DPO and LEV has $\mathrm{R}^{2}$ of 0.1 which implies that LEV explain the variation of DPO by 10 percent, also the prob of 0.8486 is significant at 95 percent Level of significance thus the joint hypothesis that LEV has no influence of on DPO cannot be rejected.

Table 7b. Coefficient Estimate between DPO and LEV.

\begin{tabular}{llllll}
\hline DPO & Coef. & Std. Err. & $\mathbf{z}$ & P>z & [95\% Conf. Interval] \\
\hline LEV & -0.0257 & 0.134592 & -0.19 & 0.849 & -0.28949 \\
_cons & $2.26 \mathrm{E}+07$ & 6578435 & 3.44 & 0.001 & 9730980 \\
Sigma_u & 9998778 & & & & \\
Sigma_e & 13611968 & & & \\
Rho & 0.35047 & (fraction of variance due to u_i) & & \\
\hline
\end{tabular}

Source: Author's estimation using STATA 12

Table $7 \mathrm{~b}$ shows that the coefficient between LEV and DPO is -0.0257 , this implies that there is negative relationship between the two variables. Moreover the findings suggest further that the relationship between the two variables is insignificant at 95 percent, as the p-value of 0.849 is greater than 0.05 level of significance. Thus the coefficient between LEV and DPO is 0.093, this suggests that when LEV increase by 1 unit then DPO will decrease by 0.0257 unit.

Table 8a. Analysis of Variance (ANOVA) between DPO and PAT.

\begin{tabular}{|c|c|c|c|}
\hline Random-effects OLS regression & Number of observation & $=$ & 32 \\
\hline Group variable: id & Number of groups & $=$ & 4 \\
\hline R-sq: within $=0.0495$ & Observations per group: $\min$ & $=$ & 8 \\
\hline between $=0.9810$ & average & $=$ & 8 \\
\hline overall $=0.5314$ & $\max$ & $=$ & 8 \\
\hline & Wald chi2 (1) & $=$ & 34.03 \\
\hline Corr $\left(\mathrm{u} \_\mathrm{i}, \mathrm{X}\right)=0$ (assumed) & Prob $>$ chi 2 & $=$ & 0 \\
\hline
\end{tabular}

Source: Author's estimation using STATA 12

Table 8a shows that the model fitted between DPO and PAT has $\mathrm{R}^{2}$ of 0.53 which implies that PAT explain the overall variation of DPO by 53 percent, also the prob of 0.00 is significant at 95 percent level of significance thus the joint hypothesis that PAT has no influence of on DPO can be rejected. These results are in line with the results of Friend and Puckett (1964), Naila (2007), Banerjee et al (2002) and Njuguna (2006). 
Table 8b. Coefficient Estimate between DPO and PAT.

\begin{tabular}{lllllll}
\hline DPO & Coef. & Std. Err. & $\mathbf{Z}$ & $\mathbf{z P}>\mathbf{Z}$ & [95\% Conf. Interval] \\
\hline PAT & 0.420561 & 0.072098 & 5.83 & 0.000 & 0.279251 & 0.561871 \\
_cons & 5281687 & 4008563 & 1.32 & 0.188 & -2574952 & $1.31 \mathrm{E}+07$ \\
Sigma_u & 0 & & & & \\
Sigma_e & 13558942 & (fraction of variance due to u_i) & & \\
Rho & 0 & &
\end{tabular}

Source: Author's estimation using STATA 12

Table $8 \mathrm{~b}$ shows that the coefficient between PAT and DPO is 0.42 , this implies that there is positive relationship between the two variables which was also observed from the correlation matrix (see table 3 ). The relationship is in line with the theoretical prediction. Moreover the findings suggest further that the relationship between the two variables is significant at 95 percent as the p-value of 0.000 is less than 0.05 Level of confidence. Thus the coefficient between PAT and DPO is 0.42 which suggests that when PAT increase by 1 unit then DPO will increase by 0.42 unit.

\section{Conclusion and Recommendations}

Only two independent variables showed significant association with the dependent variable, namely: Profit after tax and Shareholders fund. Therefore two null hypotheses were rejected and other two accepted. The findings of the study show that profit after tax (PAT) and shareholders fund (SHF) are determinants of dividend payout or dividend policies of companies listed with DSE. Liquidity (LIQ) explains little about the dividend policies and its effect is insignificant at 95 percent. Furthermore the findings reveal that there is a negative relationship between Leverage (LEV) and dividend payout (DPO). The correlation result reveals that Profit after tax is the main determinant of dividend payout of the listed companies under study.

From the findings of the study, the researcher concludes that the dividend policies and consequently dividend payouts of companies listed at the DSE is determined by the amount of profit after tax earned by the companies and the Level of Liquidity of the companies.

Among these four determinants of dividend policy, Profit after tax is the most significant determinant of dividend policy. Since profitability of a company depends on how it manages its investments, companies with better investment returns have better profitability and are hence more likely to offer higher levels of dividend payouts. Thus, the dividend policy of listed companies depends much on their current financial positions.

The study makes the following recommendations

Listed company should adopt dividend policy based on their current financial circumstances, especially, based on their current profitability positions which inturn affect the liquidity position. Also DSE should conduct frequent training to shareholders of various companies listed at DSE so as to help them make sound financial decisions with regard to which companies to buy shares from.

Further research should be conducted on how behavioral finance affects dividend policy. The dividend puzzle still exists; as to what really determines dividend policy. The determinants of dividend policy seem to also be affected by the behavior of management.

\section{References}

[1] Aivazian, V., Booth, L. and Cleary, S. (2003a). "Do emerging markets firms follow different dividend policies from U.S. firms?" Journal of Financial Research, 26: 37187.

[2] Baker, H. K., E. T. Veit \& G. E. Powell. (2001). Factors Influencing Dividend Policy Decisions of Nasdaq Firms. The Financial Review, Eastern Finance Association, (August).

[3] Baker, H. K., Veit, E. T. and Powell, G. E. (2002). "Revisiting the Dividend Puzzle: Do all the pieces now fit?" Review of Financial Economics, 38: 17-35.

[4] Barber, B. M. and Castanias, R. C. (1992). "Why do firms initiate dividends?" Unpublished working papers.

[5] Banerjee, S., V. Gatchev \& P. Spindt. (2002). To Pay or Not to Pay? The Dividend Dilemma of the LIQuid Firm. Working paper, Tulane University, New Orleans, Louisiana, November.

[6] Bhattacharya, S. (1979). "Imperfect information, dividend policy and the bird-in-hand fallacy". Bell Journal of Economics, 10: 259-270.

[7] Black, F. (1976). "The Dividend Puzzle". The Journal of Portfolio Management, 2: 5-8.

[8] Donaldson, G (1961). “Corporate Debt Capacity", Harvard: Harvard University Press

[9] DSE (2011), "Blueprint". The council of the Dar es Salaam Stock Exchange.

[10] Easterbrook, E (1984). "Two agency cost explanations of dividends". American Economic Review, 74: 650-9.

[11] Forbes, SM and Hatem J, (1998). "NYSE and AMEX listed firms that pay no-dividends: a recent history". Journal of Financial and Strategic decisions, 11: 47-51.

[12] Friend, I. and Puckett, M. (1964), Dividends and stock prices. American Economic Review, Vol. 54, Issue 5, pp. 656 - 682.

[13] Gordon, M J, (1959). "Dividends, Earnings and Stock Prices". The Review of Economics and Statistics, 41: 99-105.

[14] Gordon, MJ, (1963). "Optimal Investment and Financing Policy”. Journal of Finance, 18: 264-272.

[15] Jensen, MC (1986). "Agency Costs of free cash flow, corporate finance and takeovers". The American Economic Review, 76: 323-329. 
[16] Julio, B and Ikenberry, DL (2004). "Reappearing dividends". Journal of Applied Corporate Finance, 16: 89-100.

[17] Kolb, RW and Rodrigez, RJ (1996). "Financial Management". $2^{\text {nd }}$ Ed. Wiley.

[18] La Porta, R, Lopez-de-Silanes, F, Shleifer, A, and Vishny, RW, (2000). "Agency Problems and Dividends Policies around the world". The Journal of Finance, 55: 1-33.

[19] Lintner, J (1962). Dividends, Earnings, LE Verage Stock prices and Supply of Capital to Corporations Review of Economics and Statistics, 44: 243-269.

[20] Litzenberger, R and Ramaswamy K (1979). "The effect of taxes and dividend on capital asset prices: Theory and Empirical evidence". Journal of Financial Economics, 7: 163195.

[21] Masulis, RW and Korwar, AN, (1986). "Seasoned Equity offerings". Journal of Financial Economics, 15: 91-118.

[22] Miller, MH and Modigliani F, (1961). "Dividend Policy, Growth and Valuation of Shares". Journal of Business, 34: 411-33.

[23] Miller, MH and Scholes, MS (1978). "Dividends and Taxes". Journal of Financial Economics, 6: 333-364.

[24] Modigliani, F (1982). "Debt, dividend policy, inflation and market valuation". The Journal of Finance, 37: 255-273.
[25] Myers, SC (1984). "The capital structure puzzle". Journal of Finance, 39: 575-592.

[26] Naila, P. J. (2007). "Factors Determining Dividend" The case of Listed Companies in Tanzania. Unpublished MBA Research Project, St. Augustine University of Tanzania, 2005.

[27] Njuguna, I. M. (2006). "Detrminants of dividend Payout: The case of Listed Companies in Kenya. Unpublished MBA Research Project, University of Nairobi.

[28] Pandey, IM (2001). "Corporate dividend policy and behaviour: The Malaysian experience". Indian Institute of Management, WP 2001: 11: 01.

[29] Rozeff, MS (1982). "Growth, beta and agency costs as determinants of dividend payout ratios". The Journal of Financial Research, 3: 249-59.

[30] Said, M. A (2006). The relationships between Dividends and Investment Decisions of Firms Quoted at the Dar-es-Salaam Stock Exchange. Unpublished MSc Finance Research Project, Mzumbe University.

[31] Shiller R. J (2003). "From Efficient Markets Theory to Behavioral Finance". Journal of Economic Perspectives, 17: 183-104.

[32] Watson, D and Head, A (2004). "Corporate Finance: Principles and Practice". Financial Times Prentice Hall, $6^{\text {th }}$ Ed. 